\title{
Tests on Alkali-Activated Slag Foamed Concrete with Various Water-Binder Ratios and Substitution Levels of Fly Ash
}

\author{
Keun-Hyeok Yang ${ }^{1 *}$, Kyung-Ho Lee ${ }^{2}$ \\ ${ }^{1}$ Department of Plant \& Architectural Engineering, Kyonggi University, Suwon, Korea; ${ }^{2}$ Department of Architectural Engineering, \\ Kyonggi University Graduate School, Seoul, Korea. \\ *Corresponding author: yangkh@kgu.ac.kr
}

Received February $16^{\text {th }}, 2013$; revised March $17^{\text {th }}, 2013$; accepted March $25^{\text {th }}, 2013$

\begin{abstract}
To provide basic data for the reasonable mixing design of the alkali-activated (AA) foamed concrete as a thermal insulation material for a floor heating system, 9 concrete mixes with a targeted dry density less than $400 \mathrm{~kg} / \mathrm{m}^{3}$ were tested. Ground granulated blast-furnace slag (GGBS) as a source material was activated by the following two types of alkali activators: $10 \% \mathrm{Ca}(\mathrm{OH})_{2}$ and $4 \% \mathrm{Mg}\left(\mathrm{NO}_{3}\right)_{2}$, and $2.5 \% \mathrm{Ca}(\mathrm{OH})_{2}$ and $6.5 \% \mathrm{Na}_{2} \mathrm{SiO}_{3}$. The main test parameters were water-to-binder $(W / B)$ ratio and the substitution level $\left(R_{F A}\right)$ of fly ash $(\mathrm{FA})$ for GGBS. Test results revealed that the dry density of AA GGBS foamed concrete was independent of the $W / B$ ratio an $R_{F A}$, whereas the compressive strength increased with the decrease in $W / B$ ratio and with the increase in $R_{F A}$ up to $15 \%$, beyond which it decreased. With the increase in the $W / B$ ratio, the amount of macro capillaries and artificial air pores increased, which resulted in the decrease of compressive strength. The magnitude of the environmental loads of the AA GGBS foamed concrete is independent of the $W / B$ ratio and $R_{F A}$. The largest reduction percentage was found in the photochemical oxidation potential, being more than $99 \%$. The reduction percentage was $87 \%-93 \%$ for the global warming potential, $81 \%-84 \%$ for abiotic depletion, $79 \%-84 \%$ for acidification potential, $77 \%-85 \%$ for eutrophication potential, and $73 \%-83 \%$ for human toxicity potential. Ultimately, this study proved that the developed AA GGBS foamed concrete has a considerable promise as a sustainable construction material for nonstructural element.
\end{abstract}

Keywords: Alkali-Activated Foamed Concrete; Granulated Ground Blast-Furnace Slag; Fly Ash; Water-to-Binder Ratio; Environmental Load

\section{Introduction}

Most of residential buildings and houses in Korea adopt a floor heating system. The floor radiation heating system is commonly estimated to be lower as much as $50 \%$ in energy consumption compared with convection heating system [1]. Furthermore, the floor heating system can be converted to a floor cooling system by using a heat pump system. As a result, several countries have been recently interested in the floor heating system to overcome the limitation of convection heating system and enhance indoor environmental quality and comfort including energy conservation. In floor heating system, foamed concrete is commonly constructed between reinforced concrete slab and finishing mortar covering heating pipes to minimize a heat loss through concrete slab and to maintain the layout of heating pipe during construction of finishing mortar, as shown in Figure 1. Hence, foamed concrete for floor heating system fundamentally requires prefera- bly lower density for lighter self-weight and lower thermal conductivity, while it also needs a minimum compressive strength at an early age to fix heating pipes and prevent its bearing failure during construction of heating pipe and finishing mortar.

In recent, various efforts have been attempted to reduce the use of ordinary Portland cement (OPC) for concrete production, because the OPC is generally estimated to be predominantly responsible for the environmental loads in the concrete industry [2,3]. One of the active alternatives for the OPC, an alkali-activated (AA) binder has begun to attract a great concern since the late 1980's, though further investigation and experimental verification on various essential performances including mechanical properties, inelastic behavior and durability need for the AA binder to practically apply to structural members. However, several reviews [4-8] reveal that the AA binder can draw a good strength gain property and beneficial environmental impact with low $\mathrm{CO}_{2}$ emission 


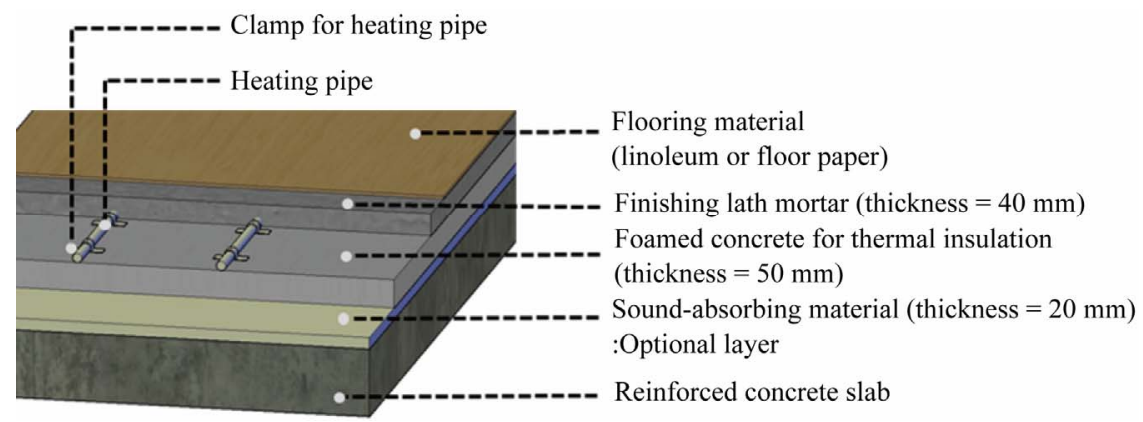

Figure 1. Typical section details of floor heating system.

and recycling of by-product materials such as ground granulated blast-furnace slag (GGBS) and fly ash (FA). Hence, AA binder would be considerable promise to produce a sustainable non-structural concrete element. Esmaily and Nuranian [9] showed that GGBS activated by sodium silicate solution can produce non-autoclaved high strength cellular concrete when the ratio of sodium silicate solution to aluminum powder for gas production is close to 1.0. Yang et al. [10] tested to develop AA GGBS foamed concrete as thermal insulation material for floor heating system and concluded that the unit binder content of approximately $400 \mathrm{~kg} / \mathrm{m}^{3}$ is required to achieve the minimum quality requirements specified in KS F 4039 [11] and ensuring the economic efficiency. On the other hand, the air-void system of foamed concrete, which significantly influences the strength and thermal conductivity of such concrete, depends on mixing proportions including water-to-binder ratio, foam volume and amount of filler as well as the performance of foam agent [12]. Furthermore, another current concern for the foamed concrete is sustainable quality. Therefore, various experiments and statistical data banks are required to establish a reliable mixing proportion for AA GGBS foamed concrete with a lower environmental impact.

The present experimental program was conducted as a follow-up to the previous investigation [10] to suggest a reasonable mixing proportion of AA GGBS foamed concrete for thermal insulation material in a floor heating system based on the various test data and understanding the behavior of such concrete. The main test parameters were water-to-binder $(W / B)$ ratio and the substitution level $\left(R_{F A}\right)$ of FA for GGBS. The quality and availability of the mixed foamed concrete were examined through comparisons with the minimum requirements (initial flow and defoamed depth for fresh concrete, and drydensity and compressive strength for hardened concrete) specified in KS F 4309 [11]. The effects of $W / B$ ratio and $\mathrm{RF}$ on the characteristics of the air-void structure of the hardened concrete were ascertained by mercury intrusion porosimetry and light optical microscope. The environmental impacts of test mixes were also compared with those calculated from a typical OPC foamed concrete mix.

\section{Experimental Details}

\subsection{Specimens and Mixing Proportions}

All specimens were classified into two groups according to the selected test parameters, as given in Table 1. The mixing details for specimens of Group I are as follows: water-to-binder $(W / B)$ ratio as the main parameter varied from $40 \%$ to $50 \%$; a combination of $10 \% \mathrm{Ca}(\mathrm{OH})_{2}$ and $4 \% \operatorname{Mg}\left(\mathrm{NO}_{3}\right)_{2}$ was used for an activator; and the unit binder content was fixed at $375 \mathrm{~kg} / \mathrm{m}^{3}$. It is noted that the binder includes the source materials and activators. For specimens of Group II, FA was substituted for GGBS with the range of $0 \%-20 \%$, and then those source materials were activated by $2.5 \% \mathrm{Ca}(\mathrm{OH})_{2}$ and $6.5 \% \mathrm{Na}_{2} \mathrm{SiO}_{3}$. The unit binder content and W/B ratio for mixes of Group II were fixed at $425 \mathrm{~kg} / \mathrm{m}^{3}$ and $37.5 \%$, respectively. The foamed concrete for a floor heating system practically requires high workability with flow above $180 \mathrm{~mm}$ for self-compactability [1]. To achieve the high workability of all mixes, high early-strength agent containing waterreducing efficiency was added for mixes of Group I by $0.2 \%$ binder content, while $0.75 \%$ naphthalene-based high-range water-reducing agent was added for mixes of Group II. The foam volume required for a given unit binder content and W/B ratio was determined based on the procedure specified in ASTM C796-97 [13] together with the unit volume of concrete.

\subsection{Materials}

The chemical compositions of GGBS and FA obtained from x-ray fluorescence (XRF) analysis are given in Table 2. The GGBS was mainly composed of calcium, silicon, alumina and magnesium oxides. The FA used had a low calcium oxide $(\mathrm{CaO})$ but was rich in both silicon and alumina as the silicon oxide $\left(\mathrm{SiO}_{2}\right)$-to-aluminum oxide $\left(\mathrm{Al}_{2} \mathrm{O}_{3}\right)$ ratio by mass is 1.91 which belongs to class $\mathrm{F}$. The Blaine fineness and specific gravity were 4400 $\mathrm{cm}^{2} / \mathrm{g}$ and 2.9 , respectively, for GGBS, and $4200 \mathrm{~cm}^{2} / \mathrm{g}$ 
Table 1. Mixing proportions of the foamed concrete specimens and summary of test results.

\begin{tabular}{|c|c|c|c|c|c|c|c|c|c|c|c|c|c|c|c|c|}
\hline \multirow{3}{*}{ Group } & \multirow{3}{*}{ Specimens } & \multirow{3}{*}{$\begin{array}{l}\text { Designed } \\
\text { foam } \\
\text { volume } \\
\text { ratio } \\
(\%)\end{array}$} & \multirow{3}{*}{$\begin{array}{c}W / B \\
\text { ratio } \\
(\%)\end{array}$} & \multirow{3}{*}{$\begin{array}{l}R_{F A} \\
(\%)\end{array}$} & \multirow{3}{*}{$\begin{array}{c}\text { Unit } \\
\text { binder } \\
\text { content } \\
\left(\mathrm{kg} / \mathrm{m}^{3}\right)\end{array}$} & \multicolumn{5}{|c|}{ Composition of AA binder by weight (\%) } & \multicolumn{3}{|c|}{ Results of fresh concrete } & \multicolumn{3}{|c|}{$\begin{array}{l}\text { Results of hardened } \\
\text { concrete }\end{array}$} \\
\hline & & & & & & GGBS & FA & $\mathrm{Ca}(\mathrm{OH})_{2}$ & $\mathrm{Na}_{2} \mathrm{SiO}_{3}$ & $\mathrm{Mg}\left(\mathrm{NO}_{3}\right)_{2}$ & Actual foam & Flow & Defoamed & Dry & $\begin{array}{r}\text { Comp } \\
\text { strengtl }\end{array}$ & $\begin{array}{l}\text { ressive } \\
\text { h (MPa) }\end{array}$ \\
\hline & & & & & & & & (\%) & (\%) & (\%) & $(\%)$ & $(\mathrm{mm})$ & $(\mathrm{mm})$ & $\left(\mathrm{kg} / \mathrm{m}^{3}\right)$ & 7 days & 28 days \\
\hline \multirow{4}{*}{ I } & $\mathrm{I}-40$ & 71.24 & 40 & \multirow{4}{*}{0} & \multirow{4}{*}{375} & \multirow{4}{*}{86} & \multirow{4}{*}{ - } & \multirow{4}{*}{10} & & \multirow{4}{*}{4} & 72.5 & $\geq 250$ & 0 & 375 & 2.15 & 3.03 \\
\hline & $\mathrm{I}-45$ & 69.37 & 45 & & & & & & & & 67.5 & $\geq 250$ & 0 & 380 & 1.26 & 1.93 \\
\hline & $\mathrm{I}-47.5$ & 68.43 & 47.5 & & & & & & & & 67.1 & $\geq 250$ & 0 & 391 & 1.06 & 1.63 \\
\hline & $\mathrm{I}-50$ & 67.49 & 50 & & & & & & & & 65.5 & $\geq 250$ & 0 & 405 & 0.95 & 1.53 \\
\hline \multirow{5}{*}{ II } & II-0 & 69.00 & & \multirow{2}{*}{\multicolumn{2}{|c|}{ 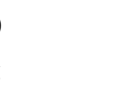 }} & 91 & \multirow{2}{*}{\multicolumn{2}{|c|}{5}} & \multirow{5}{*}{6.5} & \multirow{5}{*}{ - } & 69.3 & 195 & 11 & 406 & 0.83 & 1.20 \\
\hline & II-5 & 68.76 & & 5 & & 86 & 5 & & & & 68.1 & 200 & 12 & 409 & 0.97 & 1.68 \\
\hline & II-10 & 68.53 & 37.5 & 10 & 425 & 81 & 10 & 2.5 & & & 67.8 & 215 & 14 & 403 & 1.54 & 2.16 \\
\hline & II-15 & 68.30 & & 15 & & 76 & 15 & & & & 67.5 & 215 & 16 & 404 & 1.39 & 1.67 \\
\hline & II-20 & 68.06 & & 20 & & 71 & 20 & & & & 67.8 & 220 & 17 & 405 & 0.87 & 1.30 \\
\hline
\end{tabular}

Note: In specimen notations, the first and second parts indicate the affiliated group and main parameter in each group, respectively. Hence, the second parts for Groups I and II refer to water-to-binder ratio and substitution level of FA for GGBS, respectively. For example, specimen I-40 indicates the foamed concrete mix with W/B ratio of $40 \%$ being affiliated to Group I, while specimen II-5 indicates the foamed concrete mix with $R_{F A}$ of $5 \%$ being affiliated to Group II. ${ }^{*}$ Concrete mixes of Group I contain high early-strength agent with water reducing efficiency by $0.2 \%$ binder content; ${ }^{* *}$ Concrete mixes of Group II contain $0.75 \%$ naphthalene-based high-range water-reducing admixture.

Table 2. Chemical composition of selected source materials (\% by mass).

\begin{tabular}{cccccccccccc}
\hline Materials & $\mathrm{SiO}_{2}$ & $\mathrm{Al}_{2} \mathrm{O}_{3}$ & $\mathrm{Fe}_{2} \mathrm{O}_{3}$ & $\mathrm{CaO}$ & $\mathrm{MgO}$ & $\mathrm{K}_{2} \mathrm{O}$ & $\mathrm{Na}_{2} \mathrm{O}$ & $\mathrm{TiO}_{2}$ & $\mathrm{SO}_{3}$ & $\mathrm{LOI}^{*}$ \\
\hline FA & 57.70 & 28.60 & 5.08 & 4.70 & 0.67 & 0.57 & 0.37 & 1.53 & 0.68 & 0.1 \\
GGBS & 34.70 & 13.80 & 0.11 & 44.60 & 4.38 & 0.48 & - & 0.74 & 0.95 & 0.24 \\
\hline
\end{tabular}

${ }^{*}$ Loss on ignition.

and 2.2, respectively, for FA. All dry powdered alkali activators were pre-blended with source materials in the dry form. The specific gravity and maximum particle sizes were 2.24 and $21.2 \mathrm{~mm}$, respectively, for $\mathrm{Ca}(\mathrm{OH})_{2}$, 2.2 and $1026.1 \mathrm{~mm}$, respectively, for $\mathrm{Na}_{2} \mathrm{SiO}_{3}, 1.56$ and $600 \mathrm{~mm}$, respectively, for $\mathrm{Mg}\left(\mathrm{NO}_{3}\right)_{2}$. The foaming agent used to produce pre-foamed foam was a vegetable-based soap-type resin that is generally applied for OPC foamed concrete.

\subsection{Mixing and Testing}

All concrete specimens were produced in accordance with the pre-foamed foam mixing procedure recommended in ASTM C796-97 [13]. To produce foam, the foaming agent was diluted with water in the ratio of 1:19 by volume and then aerated to a density of $40 \mathrm{~kg} / \mathrm{m}^{3}$ using a foam generator. The pre-formed foam was added to cementitious slurry and then mixed in a $0.12-\mathrm{m}^{3}$ capacity circulating mixer pan.

For the fresh concrete, the initial flow tested without raising and dropping the flow table and defoamed depth were recorded in accordance with KS F 4039 [11]. The actual foam volume in the fresh concrete was also measured using a mess cylinder and methyl alcohol, with reference to the method proposed by Lee et al. [14]. The compressive strength of concrete was measured using $100 \times 200 \mathrm{~mm}$ cylinder at ages of 7 and 28 days. The dry density of hardened concrete was measured in accordance with KS F 2459 [11]. The pore size distribution and air-void structure were recorded at an age of 28 days by mercury intrusion porosimetry under pressures of 0 $200 \mathrm{MPa}$, and by a light optical microscope, respectively. The inside of the steel molds to test the properties of hardened concrete were lined with stiff vinyl to prevent interaction with the mold release oil. Immediately after casting, most specimens were then sealed using a plastic bag to prevent evaporation and then cured at room temperature.

\section{Test Results and Discussion}

Test results are summarized in Table 1. As the foam content generally plays a leading factor in the foamed concrete with excessively low density [12], precisely controlling the designed foam volume being pumped into the cementitious slurry is essential to achieve the targeted properties of such concrete. However, an error between the actual foam content and designed value would be sometimes occurred because the density of pre-formed foam somewhat varies with the aerating time, pressure of compressed air connected with the foam generator and 
atmospheric temperature. In the present test, the differences between the actual and the designed foam volumes were no more than $3 \%$, indicating that the mixing and pumping of the pre-formed foam were successfully achieved as intended. Hence, the designed foam volume is used for the following discussion.

\subsection{Flow of Fresh Concrete}

All mixes showed the initial flow more than $180 \mathrm{~mm}$, which is the minimum requirement value specified in $\mathrm{KS}$ F 4039 [11] (see Table 3). The value of initial flow of concrete mixes of Group I exceeded the diameter of table for measuring flow, though higher flow was visually observed with the increase in $W / B$ ratio. The substitution of FA slightly contributed to improving the flow of AA GGBS foamed concrete, showing a higher flow with the increase in the substitution level $\left(R_{F A}\right)$ of FA. The flow of fresh concrete demonstrates that the alkali activators selected for the present tests were effective in achieving high workability and preventing quick setting of the foamed concrete.

\subsection{Defoamed Depth}

The defoam in mixes of Group I almost did not occur, indicating that these specimens meet the requirement for Grade 0.6 of KS F 4039 [11]. On the contrary, $\mathrm{Ca}(\mathrm{OH})_{2}$ and $\mathrm{Na}_{2} \mathrm{SiO}_{3}$-activated concrete mixes of Groups II showed relatively high defoamed depth. In particular, the defoamed depth increased with $\underline{R}_{F A}$, indicating that the defoamed depth exceeded the minimum requirements for Grade 0.4 of KS F 4039 when the $R_{F A}$ is above $15 \%$. Severe defoam causes the deterioration of the thermal insulation capacity of the foamed concrete and cracking and settlement of the finishing lath mortar. From the comparison of activators used in Groups I and II, it can be inferred that $\mathrm{Na}_{2} \mathrm{SiO}_{3}$ as an activator is unfavorable to produce AA GGBS foamed concrete in terms of a burst of bubbles. The substitution of FA also accelerates the burst of bubbles in AA GGBS foamed concrete.

\subsection{Dry Density}

At the same unit binder content, the dry density of the foamed concrete increased slightly with the $W / B$ ratio owing to the decrease in foam content, as given in Table 1. The effect of replacement of FA on the dry density of AA GGBS foamed concrete was negligible, although the specific gravity of FA is lower than that of GGBS. The concrete mixes of Group I commonly met the density requirements of Grade 0.4 specified in KS F 4039, whereas those of Group II was relevant to Grade 0.5. Yang et al. [10] proposed that the dry density of the foamed concrete is proportional to its nominal unit weight $\left(W_{n}=W_{B}+W_{W}+W_{f}\right)$ of the plastic mix based on absolute volume, where $W_{B}, W_{W}$, and $W_{f}$ are the weights per unit volume of the binder, water and pre-foamed foam, respectively. The present tests also confirmed that the dry density of the AA GGBS foamed concrete can be expressed in terms of its nominal unit weight, as shown in Figure 2.

\subsection{Compressive Strength}

All concrete mixes achieved the minimum strength requirements of Grade 0.5 specified in KS F 4039. As might be expected, the compressive strength of the AA GGBS foamed concrete decreased with the increase in the $W / B$ ratio, as given in Table 1 . In general, concrete mixes in Group II developed lower strength than those in Group I. This indicates that $10 \% \mathrm{Ca}(\mathrm{OH})_{2}$ and $4 \%$ $\mathrm{Mg}\left(\mathrm{NO}_{3}\right)_{2}$ activators is more favorable than $2.5 \%$ $\mathrm{Ca}(\mathrm{OH})_{2}$ and $6.5 \% \mathrm{Na}_{2} \mathrm{SiO}_{3}$ activators in developing the compressive strength of AA GGBS concrete. The substitution of FA also significantly influenced the compressive strength of AA GGBS foamed concrete, showing that the compressive strength increased up to $R_{F A}$ of $15 \%$, beyond which it turned to decrease.

\subsection{Porosity and Pore Structure}

Figure 3 shows the effect of the $W / B$ ratio on the pore size distribution of AA GGBS foamed concrete. It was fail to measure the pore size distribution in mixes of Group II. The air-void structure of mixes tested is also shown in Figure 4. The macro capillaries $(50 \leq \phi<50$ $\mu \mathrm{m})$ and artificial air pores $(50 \mu \mathrm{m} \leq \phi)$ result from the deliberately entrained air and insufficient compaction,

Table 3. Quality and grade of foamed concrete for thermal insulation specified in KS.

\begin{tabular}{|c|c|c|c|c|c|c|c|}
\hline \multirow{3}{*}{ Grade } & \multicolumn{3}{|c|}{ Fresh concrete } & \multicolumn{4}{|c|}{ Hardened concrete } \\
\hline & \multirow{2}{*}{$\begin{array}{l}\text { Wet density of slurry } \\
\qquad\left(\mathrm{kg} / \mathrm{m}^{3}\right)\end{array}$} & \multirow{2}{*}{$\begin{array}{l}\text { Flow } \\
(\mathrm{mm})\end{array}$} & \multirow{2}{*}{$\begin{array}{l}\text { Defoamed depth } \\
(\mathrm{mm})\end{array}$} & \multirow{2}{*}{$\begin{array}{l}\text { Dry density } \\
\left(\mathrm{kg} / \mathrm{m}^{3}\right)\end{array}$} & \multicolumn{2}{|c|}{ Compressive strength $(\mathrm{MPa})$} & \multirow{2}{*}{$\begin{array}{l}\text { Thermal conductivity } \\
\qquad(\mathrm{W} / \mathrm{mK})\end{array}$} \\
\hline & & & & & 7 days & 28 days & \\
\hline 0.4 & $\geq 390$ & & $\leq 15$ & $300-400$ & $\geq 0.5$ & $\geq 0.8$ & $\leq 0.13$ \\
\hline 0.5 & $\geq 520$ & $\geq 180$ & $\leq 10$ & $400-500$ & $\geq 0.9$ & $\geq 1.4$ & $\leq 016$ \\
\hline 0.6 & $\geq 720$ & & $\leq 6$ & $500-700$ & $\geq 1.5$ & $\geq 2.0$ & $\leq 0.19$ \\
\hline
\end{tabular}




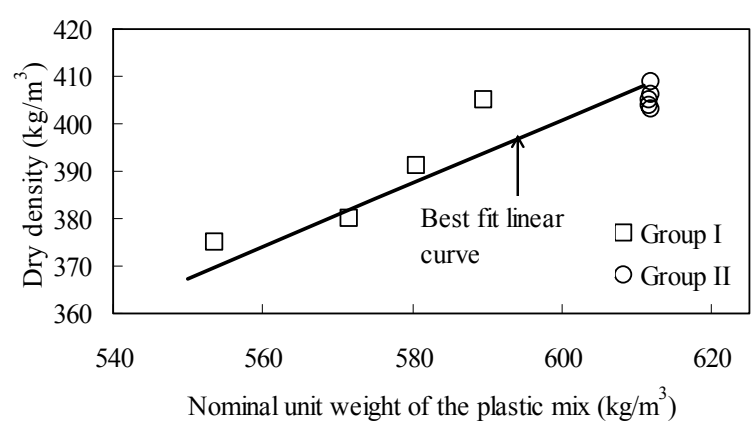

Figure 2. Relationship of nominal unit weight and dry density.

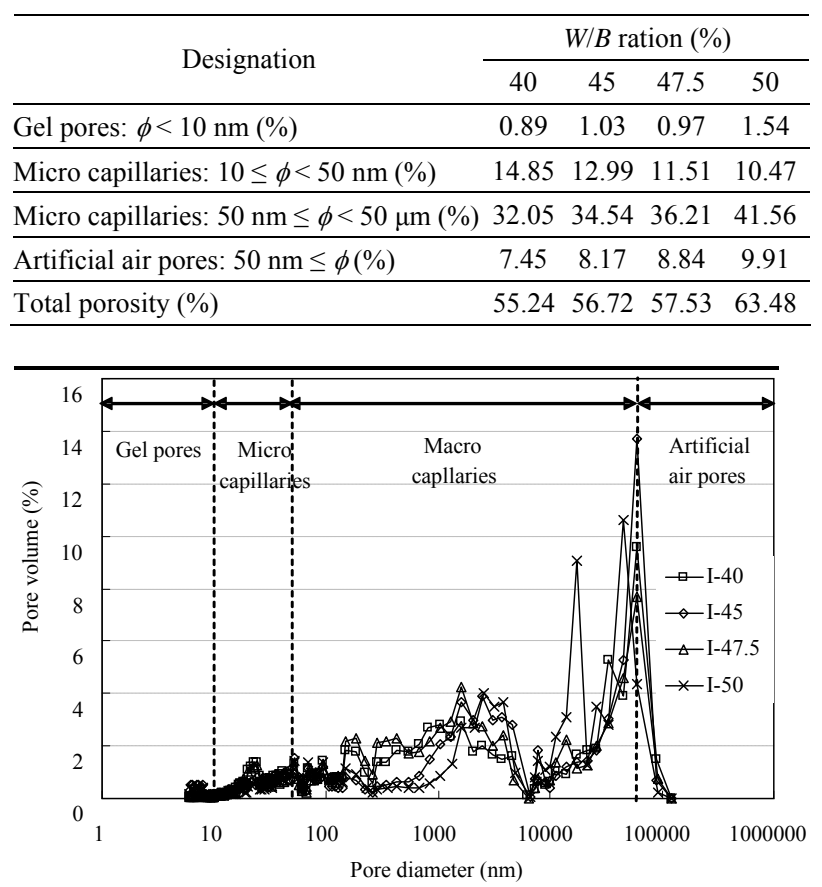

Figure 3. Effect of $W / B$ ratio on the pore size distribution.

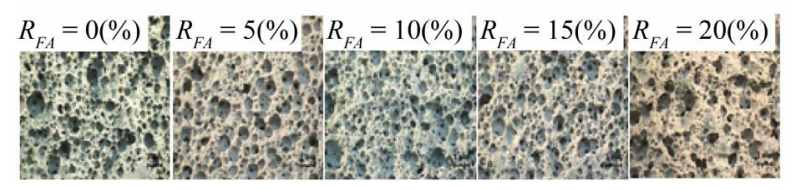

(a)

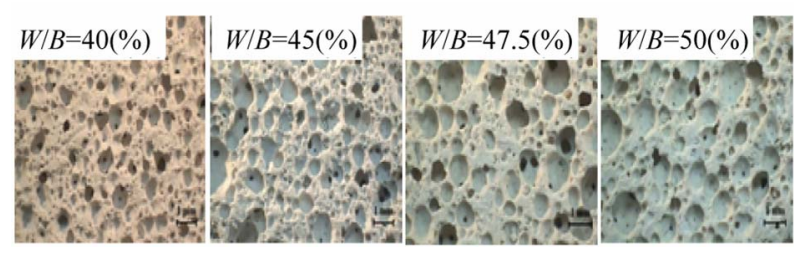

(b)

Figure 4. Air-void structure of AA GGBS foamed concrete. (a) Effect of $W / B$ ratio; (b) Effect of $R_{F A}$.

where $\phi$ is the pore diameter. With the increase in the W/B ratio, the amount of micro capillaries decreased whereas those of macro capillaries and artificial air pores increased, which resulted in the increase in porosity. In addition, a few bigger-sized pores were found, and their number also increased in concrete with higher $W / B$ ratio. On the other hand, the amount of bigger-sized pores decreased with the increase in $R_{F A}$ up to $10 \%$, beyond which it increased. The effect of test parameters on pore size distribution and air-void structure of the foamed concrete was coincident with the observation in compressive strength. This indicates that the increase of macro capillaries and artificial air pores are responsible for reduction in strength.

\section{Environmental Impact}

The environmental loads of foamed concrete were calculated in accordance with the lifecycle assessment (LCA) procedure specified in ISO 14040 series [15] based on the Korean lifecycle inventory (LCI) database [16]. The studied boundary condition was from the cradle to the pre-construction system including various contributions that are subdivided into the constituent phase, production phase using a mixer in the construction site, and transportation phase from the gate of the raw material-producing facility to the site. The LCI for a building material provides a collective data set that covers everything from the cradle to the grave. The $\mathrm{CO}_{2}$ inventory for the concrete production phase was obtained from the conversion of energy sources consumed in the mixer. The procedure and typical examples of LCA for various environmental loads are explained in detail in literature [17].

Table 4 summarizes the magnitude of the environmental loads determined from the mixing proportion of each specimen based on the LCA procedure. The environmental load inventories obtained from the typical OPC foamed concrete used for cost comparisons are also given for comparisons. The $W / B$ ratio, unit binder content and designed foam volume ratio of OPC foamed concrete were typically assumed to be $50 \%, 425 \mathrm{~kg} / \mathrm{m}^{3}$, and $65 \%$, respectively, based on the case investigation result [1]. Because the $\mathrm{CO}_{2}$ inventory of $\mathrm{Na}_{2} \mathrm{SiO}_{3}$ are considerably higher than those of $\mathrm{Ca}(\mathrm{OH})_{2}$ and $\mathrm{Mg}\left(\mathrm{NO}_{3}\right)$, the $\mathrm{CO}_{2}$ emission of concrete mixes of Group II was commonly higher than those of mixes of Group I. The magnitude of the environmental loads of the AA GGBS foamed concrete tested is independent of the $W / B$ ratio and $R_{F A}$.

The magnitude of the environmental loads of the foamed concrete tended to be remained constant regardless of the $W / B$ ratio and $R_{F A}$. This is because the unit binder content, which governs the environmental load of concrete, was fixed in each group. Among the environmental load measures in each AA GGBS mix, the largest was the $\mathrm{CO}_{2}$ emission which was followed by the consumption of natural gas. The $\mathrm{CO}_{2}$ emission of AA GGBS 
Table 4. Environmental load inventories of each concrete mix calculated from LCA procedure.

\begin{tabular}{|c|c|c|c|c|c|c|c|c|c|}
\hline \multirow{3}{*}{ Specimen } & \multicolumn{9}{|c|}{ Environmental load inventories $\left(\mathrm{kg} / \mathrm{m}^{3}\right)$} \\
\hline & \multicolumn{5}{|c|}{ Emissions } & \multicolumn{4}{|c|}{ Primary energy use } \\
\hline & $\mathrm{CO}_{2}$ & $\mathrm{CO}$ & $\mathrm{SO}_{\mathrm{X}}$ & $\mathrm{NO}_{\mathrm{X}}$ & $\mathrm{NH}_{3}$ & $\begin{array}{c}\text { Anthracite } \\
\text { coal }\end{array}$ & $\begin{array}{l}\text { Bituminous } \\
\text { coal }\end{array}$ & $\begin{array}{l}\text { Natural } \\
\text { gas }\end{array}$ & $\begin{array}{c}\text { Crude } \\
\text { oil }\end{array}$ \\
\hline $\mathrm{I}-40$ & $3.18 \mathrm{E}+01$ & $2.20 \mathrm{E}-02$ & $3.45 \mathrm{E}-02$ & $2.29 \mathrm{E}-01$ & $3.62 \mathrm{E}-03$ & $7.36 \mathrm{E}-01$ & $4.04 \mathrm{E}-03$ & $1.51 \mathrm{E}+01$ & $2.44 \mathrm{E}+00$ \\
\hline $\mathrm{I}-45$ & $3.18 \mathrm{E}+01$ & $2.20 \mathrm{E}-02$ & $3.45 \mathrm{E}-02$ & $2.29 \mathrm{E}-01$ & $3.62 \mathrm{E}-03$ & $7.36 \mathrm{E}-01$ & $4.04 \mathrm{E}-03$ & $1.51 \mathrm{E}+01$ & $2.44 \mathrm{E}+00$ \\
\hline $\mathrm{I}-47$ & $3.18 \mathrm{E}+01$ & $2.20 \mathrm{E}-02$ & $3.45 \mathrm{E}-02$ & $2.29 \mathrm{E}-01$ & $3.62 \mathrm{E}-03$ & $7.36 \mathrm{E}-01$ & $4.04 \mathrm{E}-03$ & $1.51 \mathrm{E}+01$ & $2.44 \mathrm{E}+00$ \\
\hline I-50 & $3.18 \mathrm{E}+01$ & $2.20 \mathrm{E}-02$ & $3.45 \mathrm{E}-02$ & $2.29 \mathrm{E}-01$ & $3.62 \mathrm{E}-03$ & $7.36 \mathrm{E}-01$ & $4.04 \mathrm{E}-03$ & $1.51 \mathrm{E}+01$ & $2.44 \mathrm{E}+00$ \\
\hline II-F00 & $5.46 \mathrm{E}+01$ & $2.97 \mathrm{E}-02$ & $4.96 \mathrm{E}-02$ & $1.56 \mathrm{E}-01$ & $2.67 \mathrm{E}-03$ & $2.10 \mathrm{E}-01$ & $2.65 \mathrm{E}-03$ & $8.91 \mathrm{E}+00$ & $6.30 \mathrm{E}+00$ \\
\hline II-F05 & $5.44 \mathrm{E}+01$ & $2.90 \mathrm{E}-02$ & $4.95 \mathrm{E}-02$ & $1.55 \mathrm{E}-01$ & $2.67 \mathrm{E}-03$ & $2.10 \mathrm{E}-01$ & $2.59 \mathrm{E}-03$ & $8.91 \mathrm{E}+00$ & $6.30 \mathrm{E}+00$ \\
\hline II-F10 & $5.42 \mathrm{E}+01$ & $2.83 \mathrm{E}-02$ & $4.93 \mathrm{E}-02$ & $1.54 \mathrm{E}-01$ & $2.67 \mathrm{E}-03$ & $2.10 \mathrm{E}-01$ & $2.52 \mathrm{E}-03$ & $8.91 \mathrm{E}+00$ & $6.30 \mathrm{E}+00$ \\
\hline II-F15 & $5.40 \mathrm{E}+01$ & $2.76 \mathrm{E}-02$ & $4.91 \mathrm{E}-02$ & $1.54 \mathrm{E}-01$ & $2.67 \mathrm{E}-03$ & $2.10 \mathrm{E}-01$ & $2.46 \mathrm{E}-03$ & $8.91 \mathrm{E}+00$ & $6.30 \mathrm{E}+00$ \\
\hline II-F20 & $5.38 \mathrm{E}+01$ & $2.68 \mathrm{E}-02$ & $4.89 \mathrm{E}-02$ & $1.53 \mathrm{E}-01$ & $2.67 \mathrm{E}-03$ & $2.10 \mathrm{E}-01$ & $2.39 \mathrm{E}-03$ & $8.91 \mathrm{E}+00$ & $6.30 \mathrm{E}+00$ \\
\hline $\mathrm{OPC}$ & $4.43 \mathrm{E}+02$ & $3.80 \mathrm{E}+01$ & $2.54 \mathrm{E}-01$ & $9.73 \mathrm{E}-01$ & $6.29 \mathrm{E}-02$ & $3.23 \mathrm{E}+00$ & $7.66 \mathrm{E}+01$ & $3.46 \mathrm{E}+00$ & $1.35 \mathrm{E}+01$ \\
\hline
\end{tabular}

foamed concrete was evaluated to be considerably reduced by $93 \%$ for mixes of Group I, and $88 \%$ for mixes of Group II, compared with that of OPC foamed concrete. The reduction percentage of each environmental impact profile of AA GGBS foamed concrete relative to the typical OPC foamed concrete is plotted in Figure 5. The selected environmental impact category included abiotic depletion, global warming potential, acidification potential, eutrophication potential, photochemical oxidation potential, and human toxicity potential. The largest reduction percentage was found in the photochemical oxidation potential, being more than $99 \%$. The reduction percentage was $87 \%$ - $93 \%$ for the global warming potential, $81 \%-84 \%$ for abiotic depletion, $79 \%-84 \%$ for acidification potential, $77 \%-85 \%$ for eutrophication potential, and $73 \%-83 \%$ for human toxicity potential. Overall, it can be concluded that the AA GGBS foamed concrete is promise as a sustainable building material with considerably reduced environmental impact.

\section{Concluding Remarks}

From the present experimental investigation and assessment of environmental impact, the following conclusions may be drawn:

1) The substitution of fly ash slightly contributed to improving the flow of AA GGBS foamed concrete.

2) $\mathrm{Na}_{2} \mathrm{SiO}_{3}$ as an activator is unfavorable to produce AA GGBS foamed concrete in terms of a burst of bubbles. The substitution of FA also accelerates the burst of bubbles in AA GGBS foamed concrete.

3) The dry density of the foamed concrete increased slightly with the $W / B$ ratio, whereas the effect of replace-

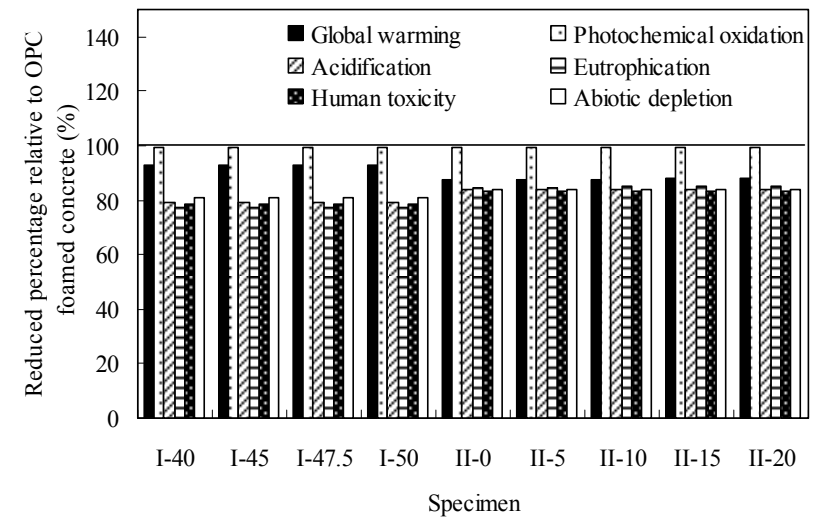

Figure 5. Reduction of each environmental impact profile of AA GGBS concrete relative to the typical OPC foamed concrete.

ment of fly ash on the dry density was negligible.

4) The compressive strength of the AA GGBS foamed concrete increased with the increase in $R_{F A}$ up to $15 \%$, beyond which it decreased.

5) With the increase in the $W / B$ ratio, the amount of micro capillaries decreased whereas those of macro capillaries and artificial air pores increased, which resulted in the increase in porosity.

6) The magnitude of the environmental loads of the AA GGBS foamed concrete tested is independent of the $W / B$ ratio and $R_{F A}$. The largest reduction percentage was found in the photochemical oxidation potential, being more than $99 \%$. The reduction percentage was $87 \%$ $93 \%$ for the global warming potential, $81 \%-84 \%$ for abiotic depletion, $79 \%$ - $84 \%$ for acidification potential, $77 \%-85 \%$ for eutrophication potential, and $73 \%-83 \%$ for human toxicity potential. 


\section{Acknowledgements}

This work was supported by the Basic Science Research Program through the National Research Foundation of Korea (NRF: 2009-0067189). The sponsor and technical participation of Hyundai Amco Co during the preparation of the test is greatly appreciated.

\section{REFERENCES}

[1] J.-K. Song and K.-H. Yang, "Development of Environmental-Friendly High-Performance Floor System," Technical Report, Department of Architectural Engineering, Chonnam National University, Gwangju, 2012.

[2] E. Gartner, "Industrially Interesting Approaches to 'Low$\mathrm{CO}_{2}$ ' Cements," Cement and Concrete Research, Vol. 34, No. 9, 2004, pp. 1489-1498. doi:10.1016/j.cemconres.2004.01.021

[3] B. L. Damineli, F. M. Kemeid, P. S. Aguiar and V. M. John, "Measuring the Eco-Efficiency of Cement Use," Cement \& Concrete Composite, Vol. 32, No. 8, 2010, pp. 555-562. doi:10.1016/j.cemconcomp.2010.07.009

[4] F. Pacheco-Torgal, J. Castro-Gomes and S. Jalali, "Alkali-Activated Binders: A Review-Part 1. Historical Background, Terminology, Reaction Mechanism and Hydration Products," Construction and Building Materials, Vol. 22, No. 7, 2008, pp. 1305-1314. doi:10.1016/j.conbuildmat.2007.10.015

[5] P. Duxson, A. Fernández-Jiménez, J. L. Provis, G. C. Lukey, A. Palomo and J. S. J. van Deventer, "Geopolmer Technology: The Current State of the Art," Journal of Material Science, Vol. 42, No. 9, 2007, pp. 2917-2933. doi:10.1007/s10853-006-0637-z

[6] C. Shi, P. V. KrddShi and D. Roy, "Alkali-Activated Cements and Concretes," Taylor and Francis, London, 2006. doi:10.4324/9780203390672

[7] S. D. Wang, X. C. Pu, K. L. Scrivener and P. L. Pratt, "Alkali-Activated Slag Cement and Concrete: A Review of Properties and Problems," Advanced Cement Research, Vol. 7, No. 27, 1995, pp. 93-102.

doi:10.1680/adcr.1995.7.27.93

[8] J. Davidovits, "Geopolymer: Chemistry \& Applications," Géopolymère, 2008.

[9] H. Esmaily and H. Nuranian, "Non-Autoclaved High Strength Cellular Concrete from Alkali Activated Slag," Construction and Building Materials, Vol. 26, No. 1, 2012, pp. 200-206.

doi:10.1016/j.conbuildmat.2011.06.010

[10] K.-H. Yang, K.-H. Lee, J.-K. Song and M.-H. Gong, "Development of Alkali-Activated Slag Foamed Concrete for Thermal Insulation," Cement \& Concrete Composite, Submitted for Publication, 2013.

[11] KS F 2459, F 4039, "Korean Industrial Standard: Testing Concrete," Korean Standards Information Center (KS), Seoul (in Korean), 2006.

[12] K. Ramamurthy, E. K. K. Nambiar and G. I. S. Ranjani, "A Classification of Studies on Properties of Foam Concrete," Cement \& Concrete Composite, Vol. 31, No. 6, 2009, pp. 388-396.

doi:10.1016/j.cemconcomp.2009.04.006

[13] ASTM C796-97, "Annual Book of ASTM Standards: V. 4.02," ASTM International, 2012.

[14] D.-H. Lee, M.-H. Jun and J.-S. Ko, "Physical Properties and Quality Control of Foamed Concrete with Fly Ash for Cast-in-Site," Journal of Korea Concrete Institute, Vol. 13, No. 1, 2001, pp. 69-76 (in Korean).

[15] ISO 14040, "Environmental Management-Life Cycle Assessment-Principles and Framework," International Standardisation Organisation 2006.

[16] Korea LCI Database Information Network, (in Korean). http://www.edp.or.kr/lcidb

[17] K.-H. Yang, J.-K. Song and K.-I. Song, “Assessment of $\mathrm{CO}_{2}$ Reduction of Alkali-Activated Concrete," Journal of Cleaner Production, Vol. 39, No. 1, 2013, pp. 265-272. doi:10.1016/j.jclepro.2012.08.001 